\title{
O LIVRO DAS PEQUENAS COISAS
}

\author{
Alckmar Santos* \\ Chico Marinho* \\ Lucas Junqueira $^{* \star}$
}

O livro das pequenas coisas foi produzido a partir da oficina "Criação poética digital" ministrada pelo coletivo formado por Nupill, 1maginário: poéticas computacionais e Ateliê Ciclope de arte e publicação digital durante o VI Simpósio Internacional e VIII Simpósio Nacional de Literatura e Informática ${ }^{1}$, realizado na Universidade de Passo Fundo entre os dias 9 e 11 de novembro de 2016. Atualmente está disponível na internete em: <http://ciclope.com.br/livrocoisas/>.

A proposta é explorar o trabalho coletivo em um ambiente digital poético e suas possibilidades em constante criação e evolução. O livro é organizado como a planta de uma casa onde alguns objetos foram escolhidos e colocado dentro de cada cômodo. A partir de uma interface $w^{2} b^{2}$, tanto os participantes da oficina quanto quaisquer outros interessados puderam - e ainda podem - contribuir com criações verbais curtas (haicais, microcontos, epigramas etc.) relacionados com esses objetos. Essas criações são então alocadas automaticamente pelo aplicativo desenvolvido para o trabalho, na interface de leitura, "dentro" dos cômodos onde normalmente são vistos.

A escolha do objeto no momento de envio da criação verbal influencia a forma como a planta da casa é exibida: cômodos com mais criações colocadas pelos participantes

\footnotetext{
* Universidade Federal de Santa Catarina, Brasil. E-mail: alckmar@gmail.com

** Universidade Federal de Minas Gerais, Brasil. E-mail: chicomar.francisco@gmail.com

*** Ateliê Ciclope de Arte e Publicação Digital, Brasil. E-mail: lucas@ciclope.art.br

1 Sítio do Simpósio: <http://www.upf.br/simposioliteraturaeinformatica>.

2 Disponível em: <http://ciclope.com.br/livrocoisas/?page_id=12>.
} 
têm uma visualização mais nítida de que aqueles que contêm menos criações. Vale salientar que um objeto pode aparecer em mais de um cômodo.

Na leitura, o usuário vai escolher um dado cômodo e, clicando na área dele, vai poder ler uma das criações que aí foi colocada aleatoriamente pelo aplicativo. Deslocandose para outro cômodo, a leitura de nova criação verbal será feita, evidentemente, com os ecos e restos da leitura anterior, emulando, no sentido verbal aí construído, a construção da própria casa, ou seja, do próprio livro-casa.

Durante a oficina, a cada um dos participantes foi solicitada a produção de um pequeno vídeo, associados a cada um dos objetos da casa. Com isso, a leitura verbal é conjugada à leitura visual dos vídeos. 